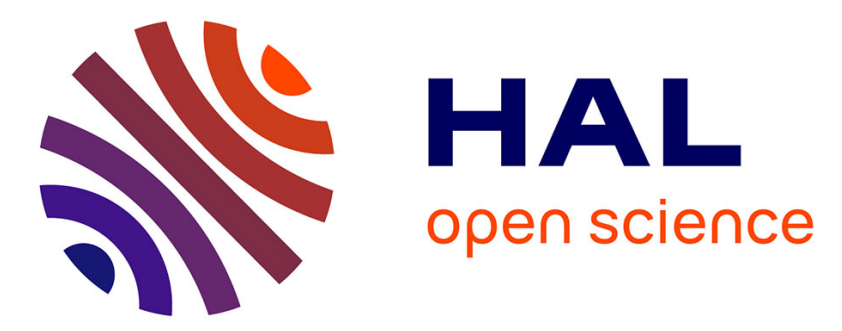

\title{
Effect of pressure-drop rate on the isolation of cananga oil using instantaneous controlled pressure-drop process
}

\author{
Magdalena Kristiawan, Vaclav Sobolik, Mazen Al Haddad, Karim Allaf
}

\section{To cite this version:}

Magdalena Kristiawan, Vaclav Sobolik, Mazen Al Haddad, Karim Allaf. Effect of pressure-drop rate on the isolation of cananga oil using instantaneous controlled pressure-drop process. Chemical Engineering and Processing: Process Intensification, 2008, 47 (1), pp.66-75. 10.1016/j.cep.2007.08.011 . hal-01213153

\section{HAL Id: hal-01213153 \\ https://hal.science/hal-01213153}

Submitted on 7 Oct 2015

HAL is a multi-disciplinary open access archive for the deposit and dissemination of scientific research documents, whether they are published or not. The documents may come from teaching and research institutions in France or abroad, or from public or private research centers.
L'archive ouverte pluridisciplinaire HAL, est destinée au dépôt et à la diffusion de documents scientifiques de niveau recherche, publiés ou non, émanant des établissements d'enseignement et de recherche français ou étrangers, des laboratoires publics ou privés. 


\title{
Effect of pressure-drop rate on the isolation of cananga oil using instantaneous controlled pressure-drop process
}

\author{
M. Kristiawan a , V. Sobolik ${ }^{\text {b,* }}$, M. Al-Haddad ${ }^{\text {b }}$, K. Allaf ${ }^{\text {b }}$ \\ ${ }^{a}$ University of Surabaya, Department of Chemical Engineering, Jalan Raya Kalirungkut, Surabaya 60293, Indonesia \\ ${ }^{\mathrm{b}}$ University of La Rochelle, Pole Sciences, Laboratory Mastering of Agro-Industrial Technologies, \\ Avenue Michel Crépeau, 17042 La Rochelle, France
}

Received 25 November 2006; received in revised form 23 August 2007; accepted 27 August 2007

Available online 31 August 2007

\begin{abstract}
The isolation of Indonesian cananga oil was carried out by a new process, instantaneous controlled pressure drop (DIC). Dry cananga flowers (Cananga odorata Hook. fil. et Thomson, forma macrophylla) were exposed for a short time to saturated steam and then the pressure was abruptly decreased to a vacuum level (about $5 \mathrm{kPa}$ ). This abrupt pressure drop provokes auto-vaporization of the superheated volatile compounds, expansion and breaking of the cell walls and instantaneous cooling. In this study, the effects of two parameters of DIC process namely pressure-drop rate and flowers moisture content on the yield of essential oil and its grouped compounds such as oxygenated monoterpenes, sesquiterpenes hydrocarbons, oxygenated sesquiterpenes and other light and heavy oxygenated compounds were studied. The oil composition was analyzed by GC coupled with MS. The availability of the volatile compounds in the residual flowers was analyzed using organic solvent extraction. The quantity of compounds obtained by DIC treatment increased with pressure-drop rate. At a rate of $1.43 \mathrm{MPa} / \mathrm{s}$ the total amount of compounds in the direct and residual oils was greater than in the reference oil obtained by chloroform extraction $(2 \mathrm{~h})$ from untreated flowers. The hydration of dry cananga flowers had no effect on the essential oil yield.
\end{abstract}

(C) 2007 Elsevier B.V. All rights reserved.

Keywords: Cananga odorata f. macrophylla; Cananga oil; Essential oil isolation; Instantaneous controlled pressure drop (DIC)

\section{Introduction}

Cananga odorata Hook. fil. et Thomson (belonging to the family of the Annonaceae) is an evergreen tree indigenous to China, Burma, Thailand, Indonesia and the Philippines. This species has been used in folk medicine for the treatment of malaria, tinea infections and fever [1]. The tree has been long cultivated on a large scale in South East Asia and some islands of the Indian Ocean, mainly Madagascar (Nossi-Bé) and the Comoro Islands for the production of essential oil from the flowers. There are two types of essential oil from $C$. odorata plants. The more precious ylang-ylang oil is isolated from the forma genuina, whereas cananga

Abbreviations: $\mathrm{dm}$, dry matter of flowers; $\mathrm{OH}$, other heavy oxygenated compounds; OL, other light oxygenated compounds; OM, oxygenated monoterpenes; OS, oxygenated sesquiterpenes; RI, retention indices relative to $\mathrm{C} 8-\mathrm{C} 32$ $n$-alkanes; S, sesquiterpenes hydrocarbons.

* Corresponding author. Tel.: +33 546458780; fax: +33 546458616.

E-mail address: vsobolik@univ-lr.fr (V. Sobolik). oil from the forma macrophylla. These two oils are used in perfumery, aromatherapy, pharmaceutical, cosmetics and food industry [2-4].

The essential oils of $C$. odorata are mostly obtained by steam distillation of fresh mature flowers and rarely by solvent extraction [2,5]. In these conventional isolation processes, the mass transfer is limited by molecular diffusion. These time-consuming processes are characterized by low isolation efficiency, loss of volatile compounds, thermal or hydrolytic degradation of the unsaturated compounds and toxic solvent residue in the extract [6]. The supercritical fluid extraction (SFE), mainly using carbon dioxide, overcomes these shortcomings. However, a high cost of the specific equipments for the high-pressure conditions (10-30 MPa) and the requirement of $\mathrm{CO}_{2}$ purity limit the use of SFE only to high added value products [6]. Moreover, this process is not selective for polar compounds and extracts also non-desirable culticular waxes and lipids $[7,8]$.

Allaf et al. [9] developed a new process, instantaneous controlled pressure drop (DIC), which isolate high quality essential 
oils in a short time. The DIC technology was originally used for texturing and drying various biological products [10]. The texturing using auto-vaporization of partially dried products (mainly cereal grains), which is known as the puffing expansion process [11,12], has been used for decades. Cereals can be puffed in several ways, from which gun puffing is the most current method. Gun puffing is based on transfer of the grain containing superheated water from a high pressure to the atmospheric pressure, thereby allowing the water to suddenly vaporize and expand the product. The DIC technology presents substantial improvements of the gun puffing. The pressure drop is towards a vacuum (about $5 \mathrm{kPa}$ ) and it is very rapid $(>0.5 \mathrm{MPa} / \mathrm{s})$. The amount of the developed vapor is greater and the product cooling is more intensive than during puffing. The final vacuum also allows the lowering of the initial pressure and thus the initial product temperature. Thereby the treatment of thermal sensitive products is possible.

Mellouk et al. [13] isolated the essential oil from juniper berries using DIC. He reported that two cycles in $150 \mathrm{~s}$ at $0.6 \mathrm{MPa}$ yielded $95 \%$ of the oil obtained by steam distillation in $12 \mathrm{~h}$. Our previous work has proved that the isolation of Indonesian cananga oil using DIC process is feasible [14]. The effect of steam pressure, heating time and number of cycles on the cananga oil yield of dry flowers was studied. An oil yield of $2.77 \%$ of dry matter was obtained with eight cycles at $0.6 \mathrm{MPa}$ in $6 \mathrm{~min}$. This yield is comparable with the yield isolated in $24 \mathrm{~h}$ using steam distillation $(2.6 \% \mathrm{dm})$.

In the present work, the effect of pressure-drop rate, i.e. the instantaneity of expansion, and initial moisture content of Indonesian cananga ( $C$. odorata $f$. macrophylla) flowers on the yield of essential oil and its grouped compounds, namely oxygenated monoterpenes, sesquiterpenes hydrocarbons, oxygenated sesquiterpenes and other light and heavy oxygenated compounds is studied. The essential oils contained in the DIC condensate and residual flowers are investigated. Residual and untreated flowers are extracted by chloroform. The oil compositions are analyzed by GC/MS.

\section{Experimental}

The experiments were carried out according to the protocol shown in Fig. 1. The research concerning cananga oil isolation using classical techniques has shown that the organic solvent extraction exhibits a higher rate and oil yield than steam distillation [15]. It was also found that chloroform extracts more polar compounds and non-volatile molecules than hexane. Based on these results, chloroform extraction during $2 \mathrm{~h}$ was used in the present work for the oil separation from untreated (reference oil) or residual flowers (residual oil). More experimental details can be found in [16].

\subsection{Materials}

Fully mature cananga flowers (C. odorata f. macrophylla) were picked at blossom in Lawang, Est Java, Indonesia. The flowers were air-dried to a final moisture content of $8.9 \% \mathrm{dm}$ and stored at room temperature prior to use.

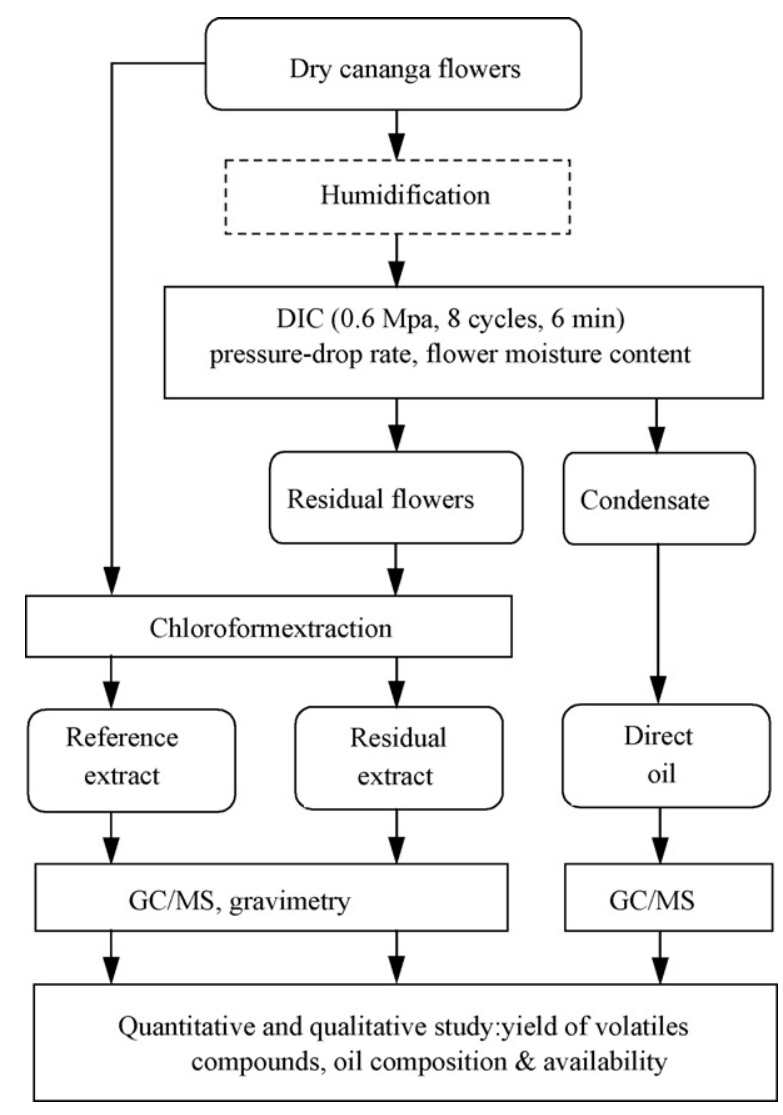

Fig. 1. Protocol for the evaluation of DIC performance in cananga oil isolation.

The dashed line boxes in Fig. 1 represent the preparation step for obtaining flowers with desired moisture content. After humidification by spraying distilled water, the cananga flowers were kept in a plastic bag for $12 \mathrm{~h}$ in a refrigerator $\left(\right.$ at $\left.4{ }^{\circ} \mathrm{C}\right)$ in order to obtain a uniform humidity.

External standard solutions at $0.2,0.6,1.2,2,3$, and $5 \mu \mathrm{g} / \mathrm{mL}$ of methyl nonadecanoate (puriss. p.a. standard for GC, Fluka, Germany) in chloroform (p.a., Carlo Erba, France) were prepared for GC/MS analysis. $\mathrm{NaCl}$ (purum p.a., Fluka, Germany), anhydrous $\mathrm{Na}_{2} \mathrm{SO}_{4}$ (p.a., Fischer Chemicals, UK) and chloroform (p.a.) were used as demulsifier, drying agent and solvent, respectively, in the liquid-liquid extraction step of the aqueous extracts; the latter was also used in the solvent extraction of untreated and residual flowers.

\subsection{Separation methods}

\subsubsection{DIC apparatus and procedure}

A schematic diagram of the DIC apparatus used for essential oil isolation is shown in Fig. 2. Dry cananga flowers $(40 \mathrm{~g}$ $\mathrm{dm}$ ) were treated in the $6 \mathrm{~L}$ autoclave (1) equipped with a double jacket, thermocouples and a pressure gauge. Steam used the product heating was injected through the valve (V1). The autoclave was connected via $80 \mathrm{~mm}$ spherical valve (V2) to a vacuum tank (2) with a volume of $285 \mathrm{~L}$. The valve was controlled by a rapid pneumatic actuator. The vacuum tank was cooled through a double jacket for condensation of the vapor, evolved by vaporization of water and volatile molecules during 


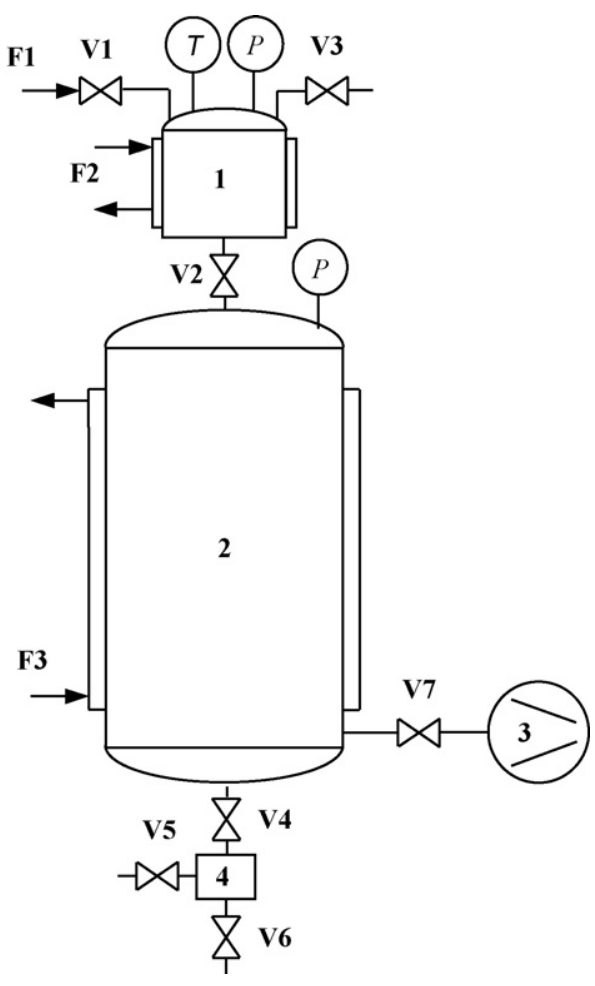

Fig. 2. Schematic diagram of the instantaneous controlled pressure-drop apparatus. (1) autoclave with heating jacket; (V2) rapid valve; (2) vacuum tank with cooling water jacket; (3) vacuum pump; (4) extract container; F1 and F2 steam flow and F3 cooling water flow.

pressure drop. Condensate was recuperated through a trap (4). A water ring pump (3) maintained the tank pressure at about $5 \mathrm{kPa}$. The atmospheric pressure in the autoclave could be installed by opening a vent (V3).

Temperature and pressure histories of one DIC cycle are shown in Fig. 3. At the beginning, the autoclave is at the atmospheric pressure (a). After opening the spherical valve, a vacuum

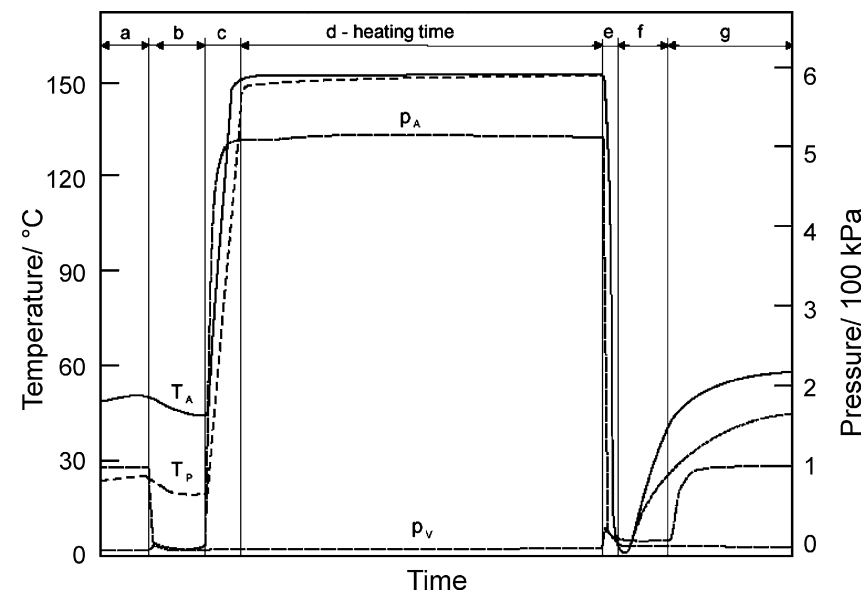

Fig. 3. Temperature and pressure history of a DIC processing cycle. $p_{\mathrm{A}}$ pressure in autoclave, $p_{\mathrm{V}}$ pressure in vacuum tank, $T_{\mathrm{A}}$ temperature in autoclave, $T_{\mathrm{P}}$ temperature of product: (a) sample at atmospheric pressure; (b) initial vacuum; (c) saturated steam injection to reach the selected pressure; (d) constant temperature corresponding to saturated steam pressure; (e) abrupt pressure drop towards vacuum; (f) vacuum and ( $\mathrm{g}$ ) releasing to the atmospheric pressure. about $5 \mathrm{kPa}$ is installed in the autoclave (b). The initial vacuum allows better penetration of the heating fluid which enhances the heat transfer in flowers. After closing this valve, saturated steam is injected into the autoclave (c) and maintained at a fixed pressure level for a predetermined time (d). At this period, the temperature in the autoclave corresponds to the temperature of the saturated steam at the pressure in the autoclave. After this thermal treatment the steam is cut off and the spherical valve is opened rapidly (in less than $0.2 \mathrm{~s}$ ) which results in an abrupt pressure drop in the autoclave (e). After the vacuum period (f), the spherical valve is closed and the atmospheric pressure installed (g).

In multi-cycle DIC process, steam is injected again after the stage (f) and the pressure is controlled for the time (d). It means that $n$ cycles contain $n$ repetition of the stages (c)-(f). The last cycle is finished by the stage $(\mathrm{g})$. The total heating time is the heating time of all cycles $(n \times \mathrm{d})$. The heating time of each cycle (d) was measured after a fixed pressure level was attained. In this work, the total heating time of six cycles was $6 \mathrm{~min}$. The total processing time was a little longer due to the short stages (c), (e) and (f).

During the abrupt pressure drop, an adiabatic vaporization of the superheated water and volatiles compounds takes place in the flowers. The vapor engenders mechanical stresses within the flowers. The blowing and breaking of cells depend on these stresses and viscoelastic behavior of the flower structure. It is a function of moisture content, temperature and heating time. The auto-vaporization as an adiabatic transformation induces also instantaneous cooling of the residual flowers (see Fig. 3). The exposure of product to a high temperature is limited to a short heating period which diminishes thermal degradation.

The following processing parameters, which resulted in a maximum oil yield in the previous study [14], were used in the present investigations: absolute steam pressure of $0.6 \mathrm{MPa}$, a total heating time of $6 \mathrm{~min}$ and right cycles. The effect of pressure-drop rate was studied with flowers having an initial moisture content $8.9 \% \mathrm{dm}$. Pressure-drop rate was modified by inserting diaphragms with different opening into the tube connecting the autoclave with the rapid valve. The effect of initial moisture content was studied with the full opening (a diameter of $80 \mathrm{~mm}$ ) at several moisture levels ranging from $8.9 \% \mathrm{dm}$ to $40 \% \mathrm{dm}$ in steps of $5 \% \mathrm{dm}$.

After the DIC treatment, the condensate (a very stable oilin-water emulsion which has droplet diameter less than $0.5 \mu \mathrm{m}$ ) was recovered from the extract container (4), and subjected to liquid-liquid extraction step with the aim to isolate essential oil. The flowers were recovered from the autoclave for residual analysis as described in Fig. 1.

\subsubsection{Pressure-drop rate}

After opening the valve between the autoclave and vacuum tank, the pressure in the autoclave drops from the initial pressure $p_{\mathrm{I}}$ to the pressure in the tank $p_{\mathrm{V}}$. The pressure in the tank stays almost constant during the pressure drop, because the volume of the autoclave is negligible compared to the tank and the vacuum pump is running. The flow into the vacuum tank can have the sonic or subsonic velocity according value of the ratio 
$p_{\mathrm{V}} /\left(p_{\mathrm{A}}-p_{\mathrm{F}}\right)$, where $p_{\mathrm{F}}$ stands for the friction losses in the connecting pipe. If this ratio is greater than the critical value $\beta$, the flow is subsonic, otherwise sonic. The critical value $\beta$ is defined by [17]

$\beta=\left(\frac{2}{\gamma+1}\right)^{\gamma /(\gamma-1)}$,

where $\gamma$ is the ratio of the specific heat at constant pressure and constant volume, $\gamma=C_{\mathrm{p}} / C_{\mathrm{v}}$. At the beginning of the pressure drop, the ratio $p_{\mathrm{V}} /\left(p_{\mathrm{A}}-p_{\mathrm{F}}\right)$ is smaller than $\beta$. It means that the flow has the sonic velocity at the pipe exit and does not depend on $p_{\mathrm{V}}$. The pressure at the pipe exit is higher than the pressure in the tank. The flow, which does not depend on the tank pressure, is called choked. The pressure drops from the exit pressure to the tank pressure in a series of shocks which are highly nonisentropic. Neglecting friction losses in the pipe, the problem can be approximated by the discharge of the autoclave through an orifice towards the constant pressure $p_{\mathrm{V}}$. The molar flow at choked conditions is given by [17]

$\dot{n}^{*}=A p_{\mathrm{A}} \sqrt{\left(\frac{2}{\gamma+1}\right)^{\gamma+1 / \gamma-1}\left(\frac{\gamma}{R T_{\mathrm{A}} M_{\mathrm{w}}}\right)}$,

where $p_{\mathrm{A}}$ and $T_{\mathrm{A}}$ are the pressure and temperature in the autoclave, $M_{\mathrm{w}}$ the molar mass of gas and $A$ the orifice area. The critical ratio $\beta$ for steam $(\gamma=1.3$ ) is equal to 0.546 . Neglecting the evaporation of condensed water and volatile compounds in the autoclave, the pressure variation is given by

$\frac{\mathrm{d} p_{\mathrm{A}}}{\mathrm{d} t}=-\frac{R T_{\mathrm{A}} \dot{n}^{*}}{V}$,

where $V$ is the volume of the autoclave. Under the assumption that $T_{\mathrm{A}}$ is constant, the pressure is the exponential function of time:

$p_{\mathrm{A}}=p_{\mathrm{I}} \exp \left(\frac{-t}{k_{\text {theor }}}\right)$

with the time constant $k_{\text {theor }}$ given by

$k_{\text {theor }}=\frac{V}{a} \sqrt{\left(\frac{\gamma+1}{2}\right)^{\gamma+1 / \gamma-1}\left(\frac{M_{\mathrm{w}}}{\gamma R T_{\mathrm{A}}}\right)}$.

The pressure-drop rate at the beginning is equal to $\mathrm{d} p_{\mathrm{A}} /\left.\mathrm{d} t\right|_{t=0}=-p_{\mathrm{I}} / k_{\text {theor }}$.

The pressure histories are shown in Fig. 4 for discharging without diaphragm and through an opening of $6 \mathrm{~mm}$. The thin curves stand for the best fitting of the initial phase by exponential curves. The experimental values of pressure-drop rate are evaluated from these curves (see Table 1). At the full opening the measured $k$ is much greater than $k_{\text {theor }}$. These two values are closer for small openings. The differences can be explained by the inertia of the pressure gauge (Keller PAA $23 \mathrm{~S}, 1 \mathrm{MPa}$ ). It must be also keep in mind that the free section grows gradually due to a final rate of the valve opening. The frictional losses in the pipe were neglected. These losses diminish the pressure difference between the pressure in the autoclave and at the pipe exit. It means that the choked flow
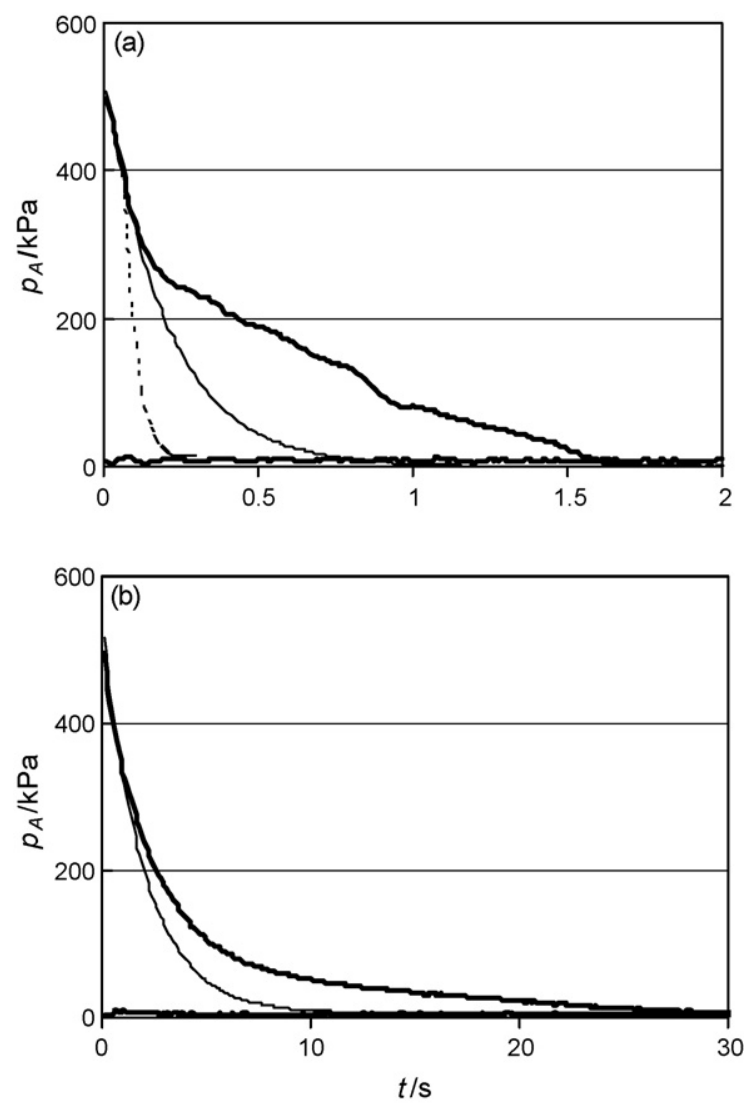

Fig. 4. Pressure-drop history in autoclave (upper thick line) and vacuum tank (lower thick line) connected with different openings: (a) $80 \mathrm{~mm}$, (b) $6 \mathrm{~mm}$. The solid thin line stands for exponential curves that best fit the beginning of the expansion. The dashed thin line in (a) stands for pressure drop of compressed air.

will change to subsonic earlier. Another effect of these losses is an enhanced exit temperature resulting in a lower molar flow. The decreasing temperature in the autoclave during expansion results in a lower volume of discharge gas. The evaporation of the water condensed on the autoclave walls increases considerably the amount of the discharged gas. The slow pressure-drop rate below $0.3 \mathrm{MPa}$ is due to this phenomenon. The thin dotted curve in Fig. 4a stands for the expansion of air. As there is no evaporation, the curve is quite exponential with exception of very beginning where the final rate of valve opening manifests itself $(k=0.05 \mathrm{~s})$. The gas dynamics of the autoclave discharge will be studied in another paper. In this work we shall refer to the experimental values of drop-rate $k$ obtained as a best fitting of the measured pressure histories in the range (0.5-0.32 MPa).

\subsubsection{Oil separation of condensate}

Prior to analysis, the critical stage was the separation of the direct oil from the condensate obtained by DIC process. The condensate was extracted three times using a separator funnel by the addition of chloroform and $\mathrm{NaCl}$ to facilitate the emulsion breakdown. Sodium sulphate was added to remove moisture and the organic phase was then concentrated under a vacuum in a rotary-evaporator at $30^{\circ} \mathrm{C}$. Each dried sample was diluted with 
Table 1

Extract yields of dry cananga flowers at different pressure-drop rates ( $p_{\mathrm{I}}=0.6 \mathrm{MPa}$, eight cycles, $\left.6 \mathrm{~min}\right)$

\begin{tabular}{|c|c|c|c|c|c|c|}
\hline Orifice diameter (mm) & 80 & 20 & 10 & 6 & 2 & 1 \\
\hline$k(\mathrm{~s})$ & 0.2 & 0.37 & 0.67 & 2 & 10 & 13.3 \\
\hline$k_{\text {theor }}(\mathrm{s})$ & 0.0041 & 0.066 & 0.26 & 0.73 & 6.6 & 26.2 \\
\hline Pressure-drop rate (MPa/s) & 2.5 & 1.43 & 0.8 & 0.27 & 0.053 & 0.04 \\
\hline DIC direct oil (\% dm) & 2.37 & 2.2 & 1.4 & 1.1 & 1.08 & 1.07 \\
\hline Oxygenated monoterpenes $(\%)$ & 6.94 & 6.95 & 7.57 & 8.19 & 7.88 & 7.85 \\
\hline OL $(\%)$ & 11.7 & 11.8 & 12.8 & 13.9 & 13.3 & 13.3 \\
\hline Sesquiterpenes hydrocarbons $(\%)$ & 27.7 & 27.9 & 26.4 & 27.9 & 27.9 & 28.0 \\
\hline Oxygenated sesquiterpenes (\%) & 38.1 & 37.9 & 37.8 & 35.5 & 36.1 & 36.1 \\
\hline $\mathrm{OH}(\%)$ & 15.6 & 15.5 & 15.4 & 14.5 & 14.8 & 14.8 \\
\hline DIC residual oil (\% dm) & 2.68 & 2.65 & 2.47 & 2.39 & 2.37 & 2.36 \\
\hline Oxygenated monoterpenes (\%) & 0.35 & 0.35 & 0.29 & 0.27 & 0.26 & 0.26 \\
\hline $\mathrm{OL}(\%)$ & 0.53 & 0.53 & 0.44 & 0.41 & 0.40 & 0.40 \\
\hline Sesquiterpenes hydrocarbons $(\%)$ & 17.8 & 17.6 & 15.8 & 15.3 & 15.2 & 15.0 \\
\hline Oxygenated sesquiterpenes (\%) & 56.5 & 56.6 & 57.9 & 58.4 & 58.4 & 58.5 \\
\hline $\mathrm{OH}(\%)$ & 24.8 & 24.9 & 25.5 & 25.7 & 25.7 & 25.8 \\
\hline DIC residual extract $(\% \mathrm{dm})$ & 23.2 & 22.6 & 19.6 & 18.3 & 18 & 17.9 \\
\hline Reference oil (\% dm) & & & 3.39 & & & \\
\hline Oxygenated monoterpenes (\%) & & & 2.45 & & & \\
\hline OL $(\%)$ & & & 4.84 & & & \\
\hline Sesquiterpenes hydrocarbons $(\%)$ & & & 30.5 & & & \\
\hline Oxygenated sesquiterpenes $(\%)$ & & & 46.8 & & & \\
\hline $\mathrm{OH}(\%)$ & & & 15.4 & & & \\
\hline Reference extract $(\% \mathrm{dm})$ & & & 10.9 & & & \\
\hline
\end{tabular}

chloroform to $20 \mathrm{~mL}$ and stored in the dark at $4{ }^{\circ} \mathrm{C}$ prior to yield and composition analysis by GC/MS.

\subsubsection{Solvent extraction of flowers}

The reference extract was obtained by the Randall technique [18] in the following way. Dry cananga flowers (4 g) were extracted with $80 \mathrm{~mL}$ of chloroform heated to boiling point during $2 \mathrm{~h}$ using a Velp Scientifica SER 148 extractor. The solution was then concentrated under a vacuum in a rotary-evaporator at $30^{\circ} \mathrm{C}$. Each dried sample was weighed for gravimetric analysis of extract yield and then diluted with chloroform to $20 \mathrm{~mL}$ and stored in the dark at $4{ }^{\circ} \mathrm{C}$ prior to analysis of oil yield and composition by GC/MS.

The residual extract was get from the residual flowers (the flowers after DIC treatment) in the same manner as the reference extract and analyzed by GC/MS.

\subsection{Analysis}

\subsubsection{Yield}

The yield of reference oil and DIC direct and residual oils is based on dry matter $(\mathrm{dm})$ of flowers:

oil yield $=\frac{\text { oil mass }}{\text { dry matter of flowers }}$,

where the oil mass was computed from GC peak area of all volatiles molecules using the external standard method with methyl nonadecanoate. DIC direct oil is composed of the volatiles molecules isolated from the DIC condensate. Reference oil contains the volatile molecules extracted from non-treated dry flowers by chloroform during $2 \mathrm{~h}$. DIC residual oil means the volatile molecules isolated from DIC-treated flowers using the same solvent and time.

The compound yield was calculated as

compound yield $=$ old yield

$$
\times \text { mass fraction of compound in oil, }
$$

where the fraction of a compound in oil (w/w) is determined from the GC peak area.

The extract yield is defined by

extract yield $=\frac{\text { extract mass }}{\text { dry matter of flowers }}$,

where the extract mass is the total mass of the extract comprising volatile oil and non-volatile molecules (resin, wax, fatty oil, colorant, etc.). The extract was obtained either from the DIC-treated or untreated flowers using chloroform extraction.

The sum of the DIC direct and residual oils was often found greater than the amount of the reference oil. The DIC treatment breaks the cellular walls and makes the compounds more available. This effect is described by the notion availability. The availability of the compound $j$ in the residual oil is defined by the following expression:

$A_{j, \mathrm{R}}=\frac{\text { yield of compound } j \text { in residual oil }}{\text { yield of compound } j \text { in reference oil }}$. 
The total availability of the compound $j$ is calculated as

$A_{j, \mathrm{~T}}=\frac{\text { yield of compound } j \text { in DIC direct and residual oils }}{\text { yield of compound } j \text { in reference oil }}$.

\subsubsection{Gas chromatography-mass spectrometry}

The volatile molecules were analyzed by gas chromatography coupled to mass spectrometry (GC/MS). A Varian computerized system comprising a 3900 gas chromatograph equipped with a fused-silica-capillary column with a non-polar stationary phase poly (dimethylsiloxane) CP-Sil $8(30 \mathrm{~m} \times 0.25 \mathrm{~mm} \times 0.25 \mu \mathrm{m}$ film thickness) was connected to a $2100 \mathrm{~T}$ mass spectrometer. The measurements were performed under the following conditions: carrier gas $\mathrm{He}$; flow rate $1 \mathrm{~mL} / \mathrm{min}$; split 1:100; injection volume $0.1 \mu \mathrm{L}$; injection temperature $250^{\circ} \mathrm{C}$; the oven temperature was increased from 60 to $170^{\circ} \mathrm{C}$ at $2.5^{\circ} \mathrm{C} / \mathrm{min}$; from 170 to $250{ }^{\circ} \mathrm{C}$ at $10 \mathrm{C} / \mathrm{min}$ and held at $250^{\circ} \mathrm{C}$ for $5 \mathrm{~min}$. The ionization mode was an electronic impact at $70 \mathrm{eV}$. Mass spectra and reconstructed chromatograms were obtained by automatic scanning in the mass range $\mathrm{m} / \mathrm{z}, 30-400 \mathrm{amu}$ at $2.2 \mathrm{scan} / \mathrm{s}$. Components were identified by comparison of their retention indices relative to $\mathrm{C}_{8}-\mathrm{C}_{32} n$-alkanes and their mass spectral fragmentation patterns with those found in the literature [19-21] and in data banks (Varian NIST MS Database 1998 and Saturn libraries). A quantitative analysis was performed by the method of peak area normalization without response factor corrections. The quantity of components was determined by the external standard method using only one authentic compound (methyl nonadecanoate). The standard curves were generated by analysis of known concentrations of methyl nonadecanoate dissolved in chloroform. Then quantification was made with linear calibration curve of external standard and dilution factor.

\section{Results and discussion}

\subsection{Effect of pressure-drop rate}

The effect of pressure-drop rate on direct and residual oil yield and composition is shown in Table 1 . The values of the reference oil are also given for comparison. The yields are also shown in Fig. 5 as a function of rate constant. The direct oil yield grows considerably with increasing pressure-drop rate. The value of $k=0.37 \mathrm{~s}$ can be considered as the limiting value that gives a satisfactory yield. This value corresponds to an initial pressuredrop rate of $1.43 \mathrm{MPa} / \mathrm{s}$. The compositions of the direct and residual oils depend on $k$. In the direct oil, the amount of oxygenated monoterpenes and other light oxygenated compounds increases with increasing $k$ whereas oxygenated sesquiterpenes and other heavy oxygenated compounds decrease. The trend is inverse in the residual oil. Sesquiterpenes hydrocarbons in direct oil do not depend on $k$. Their content in residual oil increases with decreasing $k$. The DIC treatment increases considerably extract yield. A yield of $10.9 \% \mathrm{dm}$ in non-treated flowers was increased on about $20 \%$ with DIC treatment. This can be explained by the degree of the broken cells which increases with pressuredrop rate. The extract consists of volatile oil and non-volatile molecules such as resin, wax, pigment, fatty oil, etc. Thus the
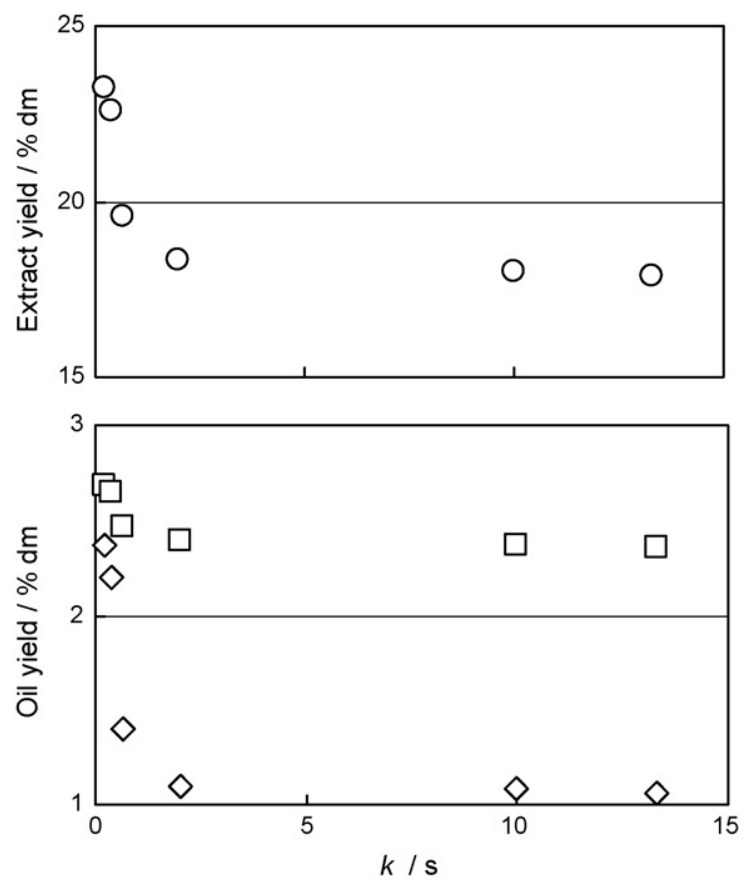

Fig. 5. Direct and residual oil and resinoid yields as a function of rate constant. $\square$, residual oil; $\diamond$, direct oil and $\bigcirc$, residual extract.

DIC treatment increases also the availability of non-volatile molecules.

The availability in residual flowers and total availability are shown in Table 2. The availability of all compounds increases with the pressure-drop rate. The availability of oxygenated monoterpenes and other light oxygenated compounds in residual flowers is very low. It means that almost all these compounds are in the direct oil. Oxygenated monoterpenes and other light oxygenated compounds are probably located mainly in the exogenous sites of the flower structure, because they evaporate easily. It is possible to isolate 1.9 times as much these

Table 2

Availability of oil compounds in residual flowers $\left(A_{\mathrm{R}}\right)$ and total availability $\left(A_{\mathrm{T}}\right)$ as a function of rate constant

\begin{tabular}{|c|c|c|c|c|c|c|}
\hline$k(\mathrm{~s})$ & 0.2 & 0.37 & 0.67 & 2 & 10 & 13.3 \\
\hline \multicolumn{7}{|c|}{ Oxygenated monoterpenes } \\
\hline$A_{\mathrm{R}}$ & 0.11 & 0.11 & 0.09 & 0.08 & 0.07 & 0.07 \\
\hline$A_{\mathrm{T}}$ & 2.09 & 1.95 & 1.36 & 1.16 & 1.10 & 1.08 \\
\hline \multicolumn{7}{|l|}{$\mathrm{OL}$} \\
\hline$A_{\mathrm{R}}$ & 0.09 & 0.08 & 0.07 & 0.06 & 0.06 & 0.06 \\
\hline$A_{\mathrm{T}}$ & 1.78 & 1.66 & 1.16 & 0.99 & 0.93 & 0.92 \\
\hline \multicolumn{7}{|c|}{ Sesquiterpenes hydrocarbons } \\
\hline$A_{\mathrm{R}}$ & 0.46 & 0.45 & 0.38 & 0.35 & 0.35 & 0.34 \\
\hline$A_{\mathrm{T}}$ & 1.10 & 1.04 & 0.73 & 0.65 & 0.64 & 0.63 \\
\hline \multicolumn{7}{|c|}{ Oxygenated sesquiterpenes } \\
\hline$A_{\mathrm{R}}$ & 0.95 & 0.94 & 0.90 & 0.88 & 0.87 & 0.87 \\
\hline$A_{\mathrm{T}}$ & 1.52 & 1.47 & 1.23 & 1.13 & 1.12 & 1.11 \\
\hline \multicolumn{7}{|l|}{$\mathrm{OH}$} \\
\hline$A_{\mathrm{R}}$ & 1.27 & 1.26 & 1.20 & 1.17 & 1.16 & 1.16 \\
\hline$A_{\mathrm{T}}$ & 1.97 & 1.91 & 1.61 & 1.48 & 1.47 & 1.46 \\
\hline
\end{tabular}

For DIC conditions see Table 1. 
Table 3

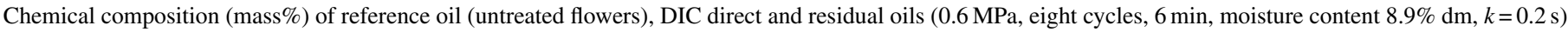

\begin{tabular}{|c|c|c|c|c|c|c|}
\hline Peak no. & RI & Compounds & Type & $\begin{array}{l}\text { Direct } \\
\text { oil }\end{array}$ & $\begin{array}{l}\text { Reference } \\
\text { oil }\end{array}$ & $\begin{array}{l}\text { Residual } \\
\text { oil }\end{array}$ \\
\hline 1 & 961 & Benzaldehyde $\left(179^{\circ} \mathrm{C}\right)$ & $\mathrm{OL}$ & 1.94 & 0.50 & 0.00 \\
\hline 2 & 985 & 6-Methyl-5-hepten-2-one & $\mathrm{OL}$ & 0.27 & 0.24 & 0.00 \\
\hline 3 & 1032 & Benzyl alcohol $\left(205^{\circ} \mathrm{C}\right)$ & $\mathrm{OL}$ & 7.84 & 3.38 & 0.37 \\
\hline 4 & 1074 & Cis-linalool oxide (furanoid form) & $\mathrm{OM}$ & 0.64 & 0.08 & 0.04 \\
\hline 5 & 1088 & Trans-linalool oxide (furanoid form) & $\mathrm{OM}$ & 0.40 & 0.00 & 0.00 \\
\hline 6 & 1098 & Linalool $\left(198^{\circ} \mathrm{C}\right)$ & $\mathrm{OM}$ & 1.90 & 0.98 & 0.07 \\
\hline 7 & 1095 & $\alpha$-Pinene oxide & $\mathrm{OM}$ & 0.26 & 0.06 & 0.07 \\
\hline 8 & 1163 & Benzyl acetate & $\mathrm{OL}$ & 0.41 & 0.22 & 0.04 \\
\hline 9 & 1240 & Neral & $\mathrm{OM}$ & 0.00 & 0.00 & 0.00 \\
\hline 10 & 1255 & Geraniol $\left(229^{\circ} \mathrm{C}\right)$ & $\mathrm{OM}$ & 3.03 & 1.00 & 0.16 \\
\hline 11 & 1270 & Geranial & OM & 0.34 & 0.08 & 0.01 \\
\hline 12 & 1351 & $\alpha$-Cubebene & $\mathrm{S}$ & 0.29 & 0.18 & 0.10 \\
\hline 13 & 1356 & Eugenol & $\mathrm{OL}$ & 0.72 & 0.23 & 0.12 \\
\hline 14 & 1376 & $\alpha$-Copaene & $\mathrm{S}$ & 1.24 & 0.93 & 0.47 \\
\hline 15 & 1383 & Geranyl acetate & $\mathrm{OM}$ & 0.37 & 0.25 & 0.00 \\
\hline 16 & 1390 & $\beta$-Cubebene & $\mathrm{S}$ & 0.16 & 0.46 & 0.00 \\
\hline 17 & 1391 & $\beta$-Elemene & $\mathrm{S}$ & 0.00 & 0.00 & 0.00 \\
\hline 18 & 1401 & Methyl eugenol & $\mathrm{OL}$ & 0.54 & 0.13 & 0.00 \\
\hline 19 & 1418 & $\beta$-Caryophyllene $\left(260^{\circ} \mathrm{C}\right)$ & $\mathrm{S}$ & 11.0 & 14.7 & 7.78 \\
\hline 20 & 1433 & $\gamma$-Elemene & $\mathrm{S}$ & 0.22 & 0.36 & 0.17 \\
\hline 21 & 1443 & $(Z)$ - $\beta$-Farnesene & $\mathrm{S}$ & 0.14 & 0.20 & 0.16 \\
\hline 22 & 1454 & $\alpha$-Humulene & $\mathrm{S}$ & 4.17 & 4.62 & 2.58 \\
\hline 23 & 1458 & $(E)-\beta$-Farnesene & $\mathrm{S}$ & 1.06 & 0.38 & 0.19 \\
\hline 24 & 1461 & Allo-aromadendrene & $\mathrm{S}$ & 0.13 & 0.00 & 0.12 \\
\hline 25 & 1477 & $\gamma$-Muurolene & $\mathrm{S}$ & 0.41 & 0.00 & 0.40 \\
\hline 26 & 1480 & Germacrene D & $\mathrm{S}$ & 1.25 & 1.99 & 0.98 \\
\hline 27 & 1490 & Cis- $\beta$-guaiene & $\mathrm{S}$ & 0.22 & 0.32 & 0.22 \\
\hline 28 & 1499 & $\alpha$-Muurolene & $\mathrm{S}$ & 0.52 & 0.39 & 0.35 \\
\hline 29 & 1500 & Trans- $\beta$-guaiene $\left(271^{\circ} \mathrm{C}\right)$ & $\mathrm{S}$ & 4.19 & 3.54 & 2.10 \\
\hline 30 & 1509 & $\beta$-Bisabolene & $\mathrm{S}$ & 0.10 & 0.09 & 0.04 \\
\hline 31 & 1513 & $\gamma$-Cadinene & $\mathrm{S}$ & 0.21 & 0.18 & 0.24 \\
\hline 32 & 1529 & $\beta$-cadinene $\left(274.5^{\circ} \mathrm{C}\right)$ & $\mathrm{S}$ & 1.04 & 0.61 & 1.11 \\
\hline 33 & 1524 & Cis-calamenene $+\delta$-cadinene & $\mathrm{S}$ & 0.78 & 0.51 & 0.40 \\
\hline 34 & 1532 & Trans-calamenene & $\mathrm{S}$ & 0.19 & 0.12 & 0.16 \\
\hline 35 & 1534 & Cadina- 1,4 diene & $\mathrm{S}$ & 0.37 & 0.08 & 0.10 \\
\hline 36 & 1534 & $(Z)-$ Nerolidol & OS & 1.26 & 0.55 & 0.43 \\
\hline 37 & 1536 & Dihydro-eugenol acetate & $\mathrm{OH}$ & 0.66 & 0.35 & 0.55 \\
\hline 38 & 1549 & Elemol & OS & 0.27 & 0.09 & 0.24 \\
\hline 39 & 1564 & (E)-Nerolidol & OS & 0.15 & 0.05 & 0.00 \\
\hline 40 & 1570 & (Z)-3-Hexenyl benzoate & $\mathrm{OH}$ & 0.30 & 0.16 & 0.10 \\
\hline 41 & 1581 & Caryophyllene oxide & OS & 17.57 & 13.51 & 6.83 \\
\hline 42 & 1583 & Globulol & OS & 0.56 & 0.52 & 0.78 \\
\hline 43 & 1596 & Cedrol & OS & 0.34 & 0.25 & 0.29 \\
\hline 44 & 1606 & Humulene epoxide II & OS & 1.91 & 3.41 & 2.30 \\
\hline 45 & 1640 & Epi- $\alpha$-cadinol & OS & 0.64 & 0.78 & 1.28 \\
\hline 46 & 1642 & Cubenol & OS & 0.25 & 0.34 & 0.60 \\
\hline 47 & 1645 & $\alpha$-Muurolol & OS & 0.51 & 0.26 & 0.25 \\
\hline 48 & 1649 & $\beta$-Eudesmol & OS & 0.79 & 0.54 & 1.27 \\
\hline 49 & 1652 & $\alpha$-Eudesmol & OS & 1.53 & 0.69 & 1.96 \\
\hline 50 & 1653 & $\alpha$-Cadinol & OS & 0.43 & 0.50 & 1.01 \\
\hline 51 & 1658 & 7-Epi- $\alpha$-eudesmol & OS & 0.56 & 0.57 & 0.70 \\
\hline 52 & 1671 & $\beta$-Bisabolol & OS & 2.08 & 0.60 & 2.96 \\
\hline 53 & 1672 & Aromadendrene oxide-(1) & OS & 0.45 & 0.84 & 1.51 \\
\hline 54 & 1678 & Aromadendrene oxide-(2) & OS & 2.90 & 2.39 & 2.53 \\
\hline 55 & 1679 & (Z)- $\alpha$-Santalol & OS & 0.76 & 1.45 & 2.53 \\
\hline 56 & 1688 & 8-Cedren-13-ol & OS & 0.61 & 2.07 & 1.20 \\
\hline 57 & 1722 & $(E, E)$-Farnesol & OS & 3.85 & 0.51 & 0.84 \\
\hline 58 & 1762 & Benzyl benzoate $\left(323^{\circ} \mathrm{C}\right)$ & $\mathrm{OH}$ & 5.89 & 7.57 & 9.12 \\
\hline 59 & 1843 & $(E, E)$-Farnesyl acetate & OS & 0.63 & 1.40 & 2.11 \\
\hline 60 & 1863 & Benzyl salicylate $\left(300^{\circ} \mathrm{C}\right)$ & $\mathrm{OH}$ & 1.41 & 3.42 & 3.60 \\
\hline 61 & 1949 & Geranyl benzoate & $\mathrm{OH}$ & 3.14 & 0.53 & 5.12 \\
\hline
\end{tabular}

The boiling points of selected compounds are at the atmospheric pressure. 


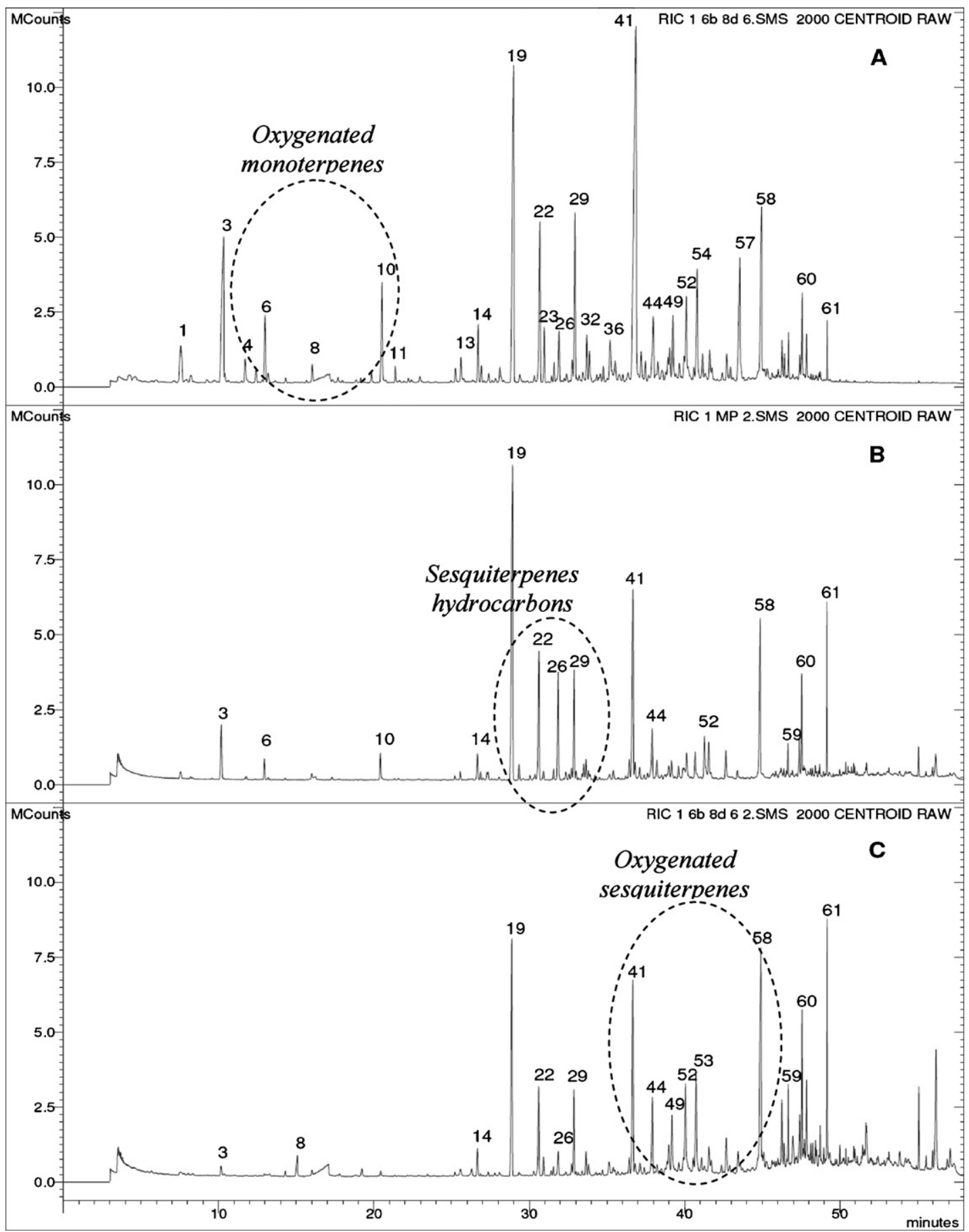

Fig. 6. Gas chromatogram of DIC direct oil (A), reference oil (B) and residual oil (C). DIC conditions: $p_{\mathrm{I}}=0.6 \mathrm{MPa}$, eight cycles, $6 \mathrm{~min}, k=0.2 \mathrm{~s}$, flowers moisture content $8.9 \% \mathrm{dm}$. See Table 4 for peak identifications.

volatiles molecules using the DIC treatment $(k=0.2 \mathrm{~s})$ than the reference oil contains. There is still a small amount of these compounds in residual oil $\left(A_{\mathrm{OM}, \mathrm{R}} \approx 0.11\right.$ and $\left.A_{\mathrm{OL}, \mathrm{R}} \approx 0.09\right)$ which is extracted from endogenous sites. Besombes et al. [22] found residual availability to be only 0.01 in the case of DIC isolation of dry lavender. It seems that the structure of cananga flowers, namely the secretory cells, is very complex and more rigid than that of lavender.

The total availability of sesquiterpenes hydrocarbons less than 1 means that they are degraded during the DIC treatment.
Nevertheless the total availability is greater than 1 at higher pressure-drop rates $(k<0.37 \mathrm{~s})$.

Oxygenated sesquterpenes and other heavy oxygenated compounds are the main compounds in residual oil. To release them completely, it is necessary to use a strong solvent (chloroform). A majority of these compounds is probably located in endogenous sites. Although a part of them, which may be in exogenous site, is released by auto-vaporization, there are still much these compounds imprisoned in endogenous site. The residual availability of oxygenated sesquterpenes and other 
heavy oxygenated compounds increases with pressure-drop rate only slightly. The pressure-drop rate has a great effect on total availability.

The detailed chemical composition of Indonesian cananga oils is given in Table 3. There are 67 compounds which makes more than $95 \%$ (mass) of the reference and direct oil and less than $90 \%$ (mass) of residual oil. The compounds that are eluted after geranyl benzoate (no. 67) were not identified. However, their availability in the residual oil is important due to the DIC treatment, see the gas chromatograms in Fig. 6. A significant quantity of some non-identified other heavy oxygenated compounds with elution time between 45 and 50 min was found in the residual oil, in contrast with their negligible quantity in the reference oil. The gas chromatograms show a reduction of oxygenated monoterpenes, other light oxygenated compounds and sesquiterpenes hydrocarbons in the residual oil compared to the reference oil. In contrast, the quantity of oxygenated sesquterpenes and other heavy oxygenated compounds in the residual oil increases significantly. The values given in Tables 1 and 2 were calculated by integration of the chromatograms until $58 \mathrm{~min}$.

\subsection{Effect of flowers moisture content}

The effect of the initial flowers moisture content $(w)$ on the yield and composition of oil was studied at the full opening of the valve $(k=0.2 \mathrm{~s})$. The moisture content was varied in the interval $(8.9 \%, 40 \% \mathrm{dm})$ with steps of $5 \%$. In contrast to the structure expansion of fruits and legume using DIC [23], $w$ had no significant effect on the yield and oil composition. Therefore, only the mean values with standard deviations measured in the above given moisture content interval are given in Table 4. Louka et al. [23] have shown that there is moisture content about $20 \%$ which gives the maximum expansion of products using one cycle DIC. This $w$ presents an optimum among the quantity of the evolved vapor and rheological properties and rate of product cooling. In the case of the using DIC for the oil isolation, two hypotheses can explain the insensitivity to humidification of dry cananga flowers by water spraying:

Table 4

Average yield of DIC ( $0.6 \mathrm{MPa}$, eight cycles, $k=0.2 \mathrm{~s})$ oils and extract at different flower moisture content $(8.9-40 \% \mathrm{dm})$

\begin{tabular}{ll}
\hline DIC direct oil $(\% \mathrm{dm})$ & $2.36 \pm 0.03$ \\
Oxygenated monoterpenes $(\%)$ & $7.40 \pm 0.2$ \\
OL (\%) & $12.5 \pm 0.4$ \\
Sesquiterpenes hydrocarbons (\%) & $24.9 \pm 0.6$ \\
Oxygenated sesquiterpenes (\%) & $39.1 \pm 0.5$ \\
OH $(\%)$ & $16.0 \pm 0.2$ \\
DIC residual oil (\% dm) & $2.82 \pm 0.09$ \\
Oxygenated monoterpenes $(\%)$ & $0.40 \pm 0.05$ \\
OL $(\%)$ & $0.61 \pm 0.07$ \\
Sesquiterpenes hydrocarbons $(\%)$ & $16.7 \pm 0.7$ \\
Oxygenated sesquiterpenes $(\%)$ & $57.1 \pm 0.5$ \\
OH $(\%)$ & $25.1 \pm 0.2$ \\
DIC residual extract $(\%$ dm) & $22.3 \pm 0.5$ \\
\hline
\end{tabular}

(i) It is impossible to replace the in situ or natural water which was bounded to the essential oil compounds in the oil cells of fresh flowers. The desiccated walls and middle lamella of cells lost their capacity of diffusion and osmosis which are the key factors for re-hydration.

(ii) The thermal and mechanical effect of eight DIC cycles is strong enough to change the flowers properties no matter what is their initial $w$. The steam diffused and condensed in the flowers during each cycle is more efficient than the sprayed water which stays on the surface.

\section{Conclusions}

The pressure-drop rate of DIC process controls the isolation of essential oil from dry cananga flowers.

An initial pressure-drop rate of $1.43 \mathrm{MPa} / \mathrm{s}$ is the limiting rate which gives a satisfactory oil yield.

Using a pressure-drop rate of $2.5 \mathrm{MPa} / \mathrm{s}$, the total availability of oxygenated monoterpenes, sesquiterpenes hydrocarbons, oxygenated sesquiterpenes, other light and heavy oxygenated compounds was 2.09, 1.10, 1.52, 1.78 and 1.97, respectively.

Oxygenated monoterpenes, other light oxygenated compounds, sesquiterpenes hydrocarbons and a part of oxygenated sesquiterpenes and other heavy oxygenated compounds in exogenous sites are extracted as direct oil by instantaneous autovaporization.

The DIC treatment increases the availability of non-volatiles compounds and the large part of oxygenated sesquterpenes and other heavy oxygenated compounds which is located in endogenous sites of residual flowers.

The re-hydration of dry cananga flowers has no effect on the DIC multi-cycle isolation of essential oil.

The DIC processing parameters must be revisited for the isolation of cananga oil from fresh flowers.

\section{Appendix A. Nomenclature}

$\begin{array}{ll}A & \text { availability (Eqs. (9) and (10)) } \\ a & \text { orifice area } \\ k & \text { time constant of pressure drop (Eqs. (4) and (5)) } \\ \dot{n}^{*} & \text { molar flow (Eq. (2)) } \\ M_{\mathrm{W}} & \text { molar mass } \\ p & \text { pressure } \\ R & \text { gas constant } \\ t & \text { time } \\ T & \text { temperature } \\ V & \text { autoclave volume } \\ w & \text { flower moisture content } \\ & \\ \text { Greek symbols } \\ \beta & \text { critical value of pressure ratio (Eq. (1)) } \\ \gamma & \text { ratio of specific heats } \\ & \\ \text { Subscripts } \\ \text { A }\end{array}$




$\begin{array}{ll}F & \text { friction losses in connecting pipe } \\ R & \text { residual } \\ \text { theor } & \text { theoretic } \\ T & \text { total } \\ V & \text { vacuum tank }\end{array}$

\section{References}

[1] E. Klein, Ylang-ylang and cananga, Dragoco Report, 9 October, 1975, pp. 167-177.

[2] F. Buccellato, Ylang survey, Perfum. Flavor. 7 (1982) 9-13.

[3] S.E. Lee, Biochemical mechanisms conferring cross-resistance to fumigant toxicities of essential oils in a chlorpyrifos-methyl resistant strain of Oryzaephilus surinamensis L. (Coleoptera: Silvanidae), J. Stored Prod. Res. 38 (2002) 157-166.

[4] J. Valnet, Aromathérapie, 11ème ed., Maloine, Paris, 1990.

[5] E.M. Gaydou, R. Randriamiharisoa, J.P. Bianchini, Composition of the essential oil of ylang-ylang (Cananga odorata Hook. fil. et Thomson, forma genuina) from Madagascar, J. Agric. Food Chem. 34 (1986) 481-487.

[6] M.D. Luque de Castro, M.M. Jiménez-Carmona, V. Fernández-Pérez, Towards more rational techniques for the isolation of valuable essential oils from plants, Trends Anal. Chem. 18 (1999) 708-716.

[7] E.E. Stashenko, N.Q. Prada, J.R. Martinez, HRGC/FID/NPD and HRGC/MSD study of Colombian ylang-ylang (Cananga odorata) oils obtained by different extraction techniques, J. High Resolut. Chromatogr. 19 (1996) 353-358.

[8] F. Gaspar, R. Santos, M.B. King, Disruption of glandular trichomes with compressed $\mathrm{CO}_{2}$ : alternative matrix pre-treatment for $\mathrm{CO}_{2}$ extraction of essential oils, J. Supercrit. Fluids 21 (2001) 11-22.

[9] K. Allaf, S.A. Rezzoug, F. Cioffi, M.P. Contento, Processus de Traitement Thermo-Mécanique par Détente Instantanée Contrôlée des Fruits, Jus et Peaux d'Agrumes, French patent no. 98/11105, 1998

[10] K. Allaf, N. Louka, J.M. Bouvier, M. Parent, M. Forget, Procédé de Traitement de Produits Végétaux et Installation pour la Mise en Oeuvre d'un Tel Procédé, French patent no. 93/09728, 1993.

[11] A.I. Varnalis, J.G. Brennan, D.B. MacDougall, A proposed mechanism of high-temperature puffing of potato. Part I. The influence of blanching and drying conditions on the volume of puffed cubes, J. Food Eng. 48 (2001) 361-367.
[12] M. Mariotti, C. Alamprese, M.A. Pagani, M. Lucisano, Effect of puffing on ultrastructure and physical characteristics of cereal grains and flours, J. Cereal Sci. 43 (2006) 47-56.

[13] H. Mellouk, G. Naji, K. Allaf, Etude de l'extraction des huiles essentielles de baies de Genievre par Détente Instantanée Contrôlée DIC comparée à l'entraînement à la vapeur, in: Proceedings de 16es Rencontres Scientifiques et Technologiques des Industries Alimentaires (Agoral), Nantes, France, 2004, pp. 265-269.

[14] M. Kristiawan, V. Sobolik, K. Allaf, Isolation of Indonesian cananga oil by Instantaneous Controlled Pressure Drop, J. Essent. Oil Res., in press.

[15] M. Kristiawan, V. Sobolik, K. Allaf, Isolation of Indonesian cananga oil. Part I. Comparison of steam distillation and organic solvent extraction, J. Food Eng., submitted for publication.

[16] M. Kristiawan, Traitement Thermo-Mécanique des Fleurs d'Ylang-Ylang Indonésienne par Détente Instantanée Contrôlée en Vue de l'Extraction de l'Huile Essentielle, Ph.D. Thesis, Université de La Rochelle, France, 2006.

[17] R.H. Perry, D.W. Green, Perry's Chemical Engineers' Handbook, 7th ed., McGraw-Hill International Editions, Singapore, 1998, pp. 6-22, $16-23$.

[18] J. Cai, B. Liu, P. Ling, Q. Su, Analysis of free and bound volatiles by gas chromatography and gas chromatography-mass spectrometry in uncased and cased tobaccos, J. Chromatogr. A 947 (2002) 267-275.

[19] R.P. Adams, Identification of Essential Oil Components by Gas chromatography/Mass Spectroscopy, Allured Publishing Corporation, Carol Stream, 1995.

[20] N.W. Davies, Gas chromatographic retention indices of monoterpenes and sesquiterpenes on methyl silicone and carbowax 20M phases, J. Chromatogr. 503 (1990) 1-24.

[21] W. Jennings, T. Shibamoto, Qualitative Analysis of Flavor and Fragrance Volatiles by Glass Capillary Gas Chromatography, Academic Press, New York, 1980.

[22] C. Besombes, O. Barkat, K. Allaf, Analyse de l'autovaporisation instantanée dans l'extraction de l'huile essentielle de lavandin, in: Proceedings de 16ème Rencontres Scientifiques et Technologiques des Industries Alimentaires (Agoral), Nantes, France, 2004, pp. 250-254.

[23] N. Louka, F. Juhel, K. Allaf, Quality studies on various types of partially dried vegetables texturized by controlled sudden decompression. General pattern for the variation of the expansion ratio, J. Food Eng. 65 (2004) 245-253. 